\title{
The Vague Awareness of Communities in the Singhasari Special Economic Zone Development during the COVID-19 Pandemic
}

\author{
Lutfi Amiruddin 1,*, (D), Genta Mahardhika Rozalinna 1, (D), and \\ Primadiana Yunita 2, \\ ${ }^{1}$ Department of Sociology, Faculty of Social and Political Sciences, \\ Universitas Brawijaya, 65145, Malang, East Java Province, Indonesia \\ 2 Department of International Relations, Faculty of Social and Political Sciences, \\ Universitas Brawijaya, 65145, Malang, East Java Province, Indonesia \\ * Corresponding Author: amiruddin.lutfi@ub.ac.id
}

\section{ARTICLE INFO}

\section{Publication Info:}

Research Article

How to cite:

Amiruddin, L., Rozalinna, G. M., E Primadiana, Y. (2021). The Vague Awareness of Communities in the Singhasari Special Economic Zone Development during the COVID-19 Pandemic. Society, 9(2), 490-503.

\section{DOI: 10.33019/society.v9i2.298}

Copyright (C) 2021. Owned by Author(s), published by Society

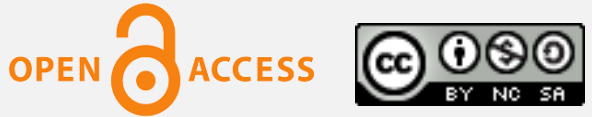

This is an open-access article.

\section{License: Attribution-}

NonCommercial-ShareAlike (CC BY-NC-SA)

Received: January 21, 2021; Accepted: March 29, 2021; Published: December 31, 2021;

\begin{abstract}
The development process of the Singhasari Special Economic Zone (SEZ) in heritage tourism has not paid attention to socialization to residents. On the other hand, the COVID-19 pandemic has also affected its development. With this situation, this research aims to identify the community's readiness of cultural activists and tourism actors in the Singhasari Special Economic Zone (SEZ). Through the concept of community readiness by searching and analyzing qualitative data, this research finds two important things; first, the community of cultural and tourism activists is still in the readiness level of vague awareness. This model of awareness stems from the distribution of unclear information. The research findings suggest that these communities only get information from gossip among themselves. Second, the COVID-19 pandemic, which slows down the development process, is interpreted as a punishment from God for the SEZ organizers. This interpretation relates to the lack of disclosure of public information regarding the SEZ development process. These two results show that there are symptoms of a crisis in developing sustainable tourism industry.
\end{abstract}

Copyright (C) 2021. Owned by Author(s), published by Society. This is an open-access article under the CC-BY-NC-SA license. https://doi.org/10.33019/society.v9i2.298

Keywords: COVID-19 Pandemic; Readiness; Tourism Industry 


\section{Introduction}

The government determines the development of Special Economic Zones (SEZ) through Law No. 39 of 2009 concerning Special Economic Zones. Singosari is one of the areas in East Java that the government has designated as a Special Economic Zone through Government Regulation of the Republic of Indonesia No. 68 of 2019. It is stated in the 2010-2029 East Java Provincial Spatial Plan. Singosari Sub-district is one of the areas selected as a Special Economic Tourism Zone because it has the advantage of heritage and historical tourism potential. In this area, there are cultural heritages, such as Singosari Temple, Sumberawan Temple, Dwarapala Statue, and other relics of the Singosari Kingdom. Singhasari Special Economic Zone (SEZ) is expected to improve the management of heritage tourism objects by developing the search for historic sites and increasing the preservation of sites, temples, and other historical relics artifacts. Also, the area's development is an object of historical tourist attraction.

In connection with the plan, Malang Regency Culture and Tourism Office in 2011-2015 explained that the problems with heritage tourism objects in the Singosari area, namely transportation facilities, and infrastructure to reach tourist objects, were still experiencing difficulties especially the damaged road conditions. Also, there is a lack of community participation in developing heritage tourism objects and a lack of planning integration between heritage tourism objects; the low management of heritage tourism destinations in packaging tourist attractions into tourism products and packages (Dinas Kebudayaan dan Pariwisata Kabupaten Malang, 2015).

According to the opinion of the Head of Malang Regency Culture and Tourism Office, Malang Regency has tourism potential, including heritage and historical tourism objects in the form of temple relics. However, the management of the historical site has not been maximized due to the lack of investment. The development of temple tourism is also constrained by the temple's location, which is located around densely populated settlements. Research to explore new sites is difficult because of the narrow land and the lack of budget of Malang Regency Culture and Tourism Office (Krisnawati \& Suprihardjo, 2014).

With the development of the Singhasari Special Economic Zone (SEZ), it is hoped that the potential for heritage tourism can be developed. Likewise, the community can use these policies to improve their economic standard. Local communities are an important part of the SEZ development process, covering an area of 120.3 hectares. Communities living in the three villages that are the location of the SEZ can certainly feel the impact of this development. Economic, social, cultural, and ecological conditions will experience changes in line with the development process that has been carried out since 2019. The National Council for Special Economic Zones of the Republic of Indonesia projects that there will be 6,863 workers absorbed by 2030, with a projected investment value of Rp11.92 Trillion (Dewan Nasional Kawasan Ekonomi Khusus Republik Indonesia, 2019).

The development process began with purchasing residents' land has been carried out since 2019. Residents in the three villages who own land, houses, and rice fields in the SEZ location must sell these assets to the developer. Likewise, people who have small businesses, such as grocery stores to food vendors, are affected by this project.

However, the COVID-19 pandemic spread since March 2020 has had a major impact on the global tourism industry sector. A study of the impact of the pandemic on the global tourism sector conducted by the United Nations World Tourism Organization (UNWTO), for example, showed that there was a decline of $22 \%$ in the first quarter of 2020. In March 2020, it fell drastically by $57 \%$, which means a loss of 67 million international arrivals and declining

Copyright (C 2021. Owned by Author(s), published by Society. This is an open-access article under the CC-BY-NC-SA license. 
revenues of around USD 80 billion (United Nations World Tourism Organization, 2020). Meanwhile, the World Travel and Tourism Council organization warns that there are 50 million jobs in the global tourism industry sector that have the potential to be lost (Faus, 2020). Although the tourism sector has been affected by the pandemic, the construction of the Singhasari SEZ will continue. The land acquisition process continues in the villages where the SEZ is located, although the process is not as fast as before the pandemic.

With all the dynamics above, it becomes important to see how prepared the community groups are in the SEZ zone. Therefore, the readiness of the local community affects the success of the development of the tourism industry. Suppose there is a positive impact obtained by the community around the tourism industry, such as increasing income, job opportunities, etc. In that case, it can lead to community involvement in tourism development (Nian et al., 2019). Without support from local communities, the sustainability of the tourism industry will be threatened. Local communities are the focal point for sustainable tourism development (Nunkoo \& Ramkissoon, 2011). Thus, the community of cultural and tourism activists has an important role in developing sustainable tourism.

Two subjects were involved in this study: the community of cultural activists and heritage tourism actors. This community of cultural activists is considered a group that preserves artifacts in temple buildings, statues, and other relics and maintains traditional values. Meanwhile, heritage tourism actors have supported the sustainability of the tourism industry, such as temple guards and food vendors around the temple. With the presence of SEZs, these groups are projected to be directly affected by the development of more massive tourism industry. These two groups will directly benefit from the development of the Singhasari SEZ.

Based on the description that has been stated above, this research aims to identify the readiness of groups of cultural activists and tourism actors in the SEZ Singhasari area to assess the factors that affect community readiness during the COVID-19 pandemic. So, in this study, the subjects selected were groups of cultural activists and tourism driving actors who were active or living in the tourism development zone included in the Singhasari SEZ.

\section{Literature Review}

\subsection{Previous Research}

Research related to the impact of the COVID-19 pandemic on the tourism industry has been widely published. Some of them are related to pandemic impact, although many discuss innovations in the tourism sector. Candra \& Rekha (2020), for example, with quantitative measurements, found that tourism actors are affected not only economically but also psychologically. Meanwhile, Riadil (2020) revealed the impact of COVID-19 by using the perspective of tourism workers, such as hotels, restaurants, and tourist attractions, who began to realize that the pandemic could threaten their work. Fathurrahim (2020) on Lombok tourism stated that the impact on the tourism industry is multiplied when it is in a post-disaster condition, such as the 2018 earthquake and the 2020 pandemic. Meanwhile, from the perspective of tourists, Uğur \& Akbiyik (2020) stated that many travelers ended up canceling tourist trips through online applications, both transportation and accommodation.

Despite having a big impact, various tourism innovations have emerged. Kaushal and Srivastava found that the presence of COVID-19 made the tourism sector in India make various adjustments to survive, such as getting used to wearing masks and washing hands for tourism actors (Kaushal \& Srivastava, 2020). Another innovation emerged in digital tourism (Gunagama et al., 2020). 
At the policy level, there is also research on recovery policies. By comparing Indonesia with Thailand, Rosyadi (2021) explained the capacity of the governments in the two countries in the tourism industry recovery strategy during the pandemic. Rosyadi considers the capacity of the Thai government to be somewhat better in recovering tourism and transmitting the virus, although corrupt practices were found in it. Rosyadi may not have seen that the corrupt practice of public aid funds also occurs in Indonesia.

If the research above examines the impact of the pandemic and innovation in the tourism sector, this research takes a different side. We see that tourism development projects during the pandemic also need to pay attention to how prepared local communities, such as cultural activists and heritage tourism actors, face this infrastructure development. The tourism industry is assumed to be developing, and local communities are the stakeholders who will be affected. For this reason, it is very important to see the readiness of the local community to face these changes. This point of view is the difference between this research and previous research. At the same time, there is a pandemic disaster situation that has become a social context that affects the tourism industry. It is this point of view that distinguishes this study from previous research.

A study on community readiness to face SEZ was conducted by Rachman \& Syamsudin (2019). They tried to describe the perception and readiness of the Pandeglang community in facing the SEZ of the Tanjung Lesung Tourism Zone. There are two things studied by Rachman \& Syamsudin (2019), namely, the perception and readiness of the community. By using a descriptive quantitative method, by distributing questionnaires from 400 respondents, it was found that the public perception of SEZ is quite good. Likewise, community readiness is categorized in a position ready to face SEZ (Rachman \& Syamsudin, 2019). What should be noted from Rachman and Zainudin's publications is that they are not listed, and the indicators of the concept of perception and readiness are not explained.

The study on community readiness to face the next SEZ comes from Lintjewas et al. (2015). Their study looked at the level of preparedness through indicators of knowledge, attitude, and response. Through his analysis, it was found that the respondents were considered ready to accept if the government determined their area as the area for the SEZ development plan. However, judging from the ability factor of each individual, it showed that the community was still not ready. This is indicated that the respondents still lack knowledge, nor have they attended training in the industrial sector (Lintjewas et al., 2015). Compared to Rachman \& Syamsudin (2019), Lintjewas et al. (2015) used several important indicators in measuring people's knowledge, attitudes, and responses.

As an SEZ that is being built, it is also necessary to conduct research related to community readiness during the development process of the Singhasari SEZ. Our research continues the research logic that has been built by Rachman \& Syamsudin (2019) and Lintjewas et al. (2015). The SEZ development process during a pandemic became a significant differentiator, resulting in our findings.

\subsection{Community Readiness}

Although it has been stipulated through Law No. 39 of 2009, SEZ was not immediately formed. This Law was later strengthened through Government Regulation of the Republic of Indonesia No. 2 of 2011 concerning the Implementation of Special Economic Zones. It was only in 2012 that the first SEZ in Indonesia, namely the SEZ of Sei Mangkei, Simalungun Regency, North Sumatra, was formed. From this government regulation, SEZs were born in several 
The Vague Awareness of Communities in the Singhasari Special Economic Zone Development during the COVID-19 Pandemic

regions in Indonesia. One designated SEZ is the Singhasari SEZ, Malang Regency, established on September 27, 2019, through Government Regulation of the Republic of Indonesia Number 68 of 2019 concerning the Singhasari Special Economic Zone. The Singhasari SEZ was built to develop tourism zones and technology development zones. Still, according to this Government Regulation of the Republic of Indonesia, the Malang Regent has the authority to determine the business entity that builds and manages the Singhasari SEZ within 90 days from the promulgation of this Government Regulation (Republik Indonesia, 2019).

Establishing it as an SEZ zone also means the emergence of a new source of economy for the local community. However, it is necessary to identify how the local community understands and prepares themselves to face this new source of economy. The more prepared people face new economic sources, the easier it will be to get involved in the new system. Or in other words, the more prepared the community in the Singhasari SEZ zone is, the easier the process of getting involved in the SEZ will be.

To describe the readiness of the local community included in the SEZ Singhasari zone, a Community Readiness Model (CRM) was taken. Community readiness is understood as the degree or extent to which a community takes action to deal with certain problems. The lowest level of readiness can range from "not prepared at all" to "taking part in solving certain problems" (Plested et al., 2006). Community readiness is considered the main factor was determining whether a program can be implemented effectively and supported by local communities (Edwards et al., 2000).

The level of readiness of a community can be seen in the following figure:

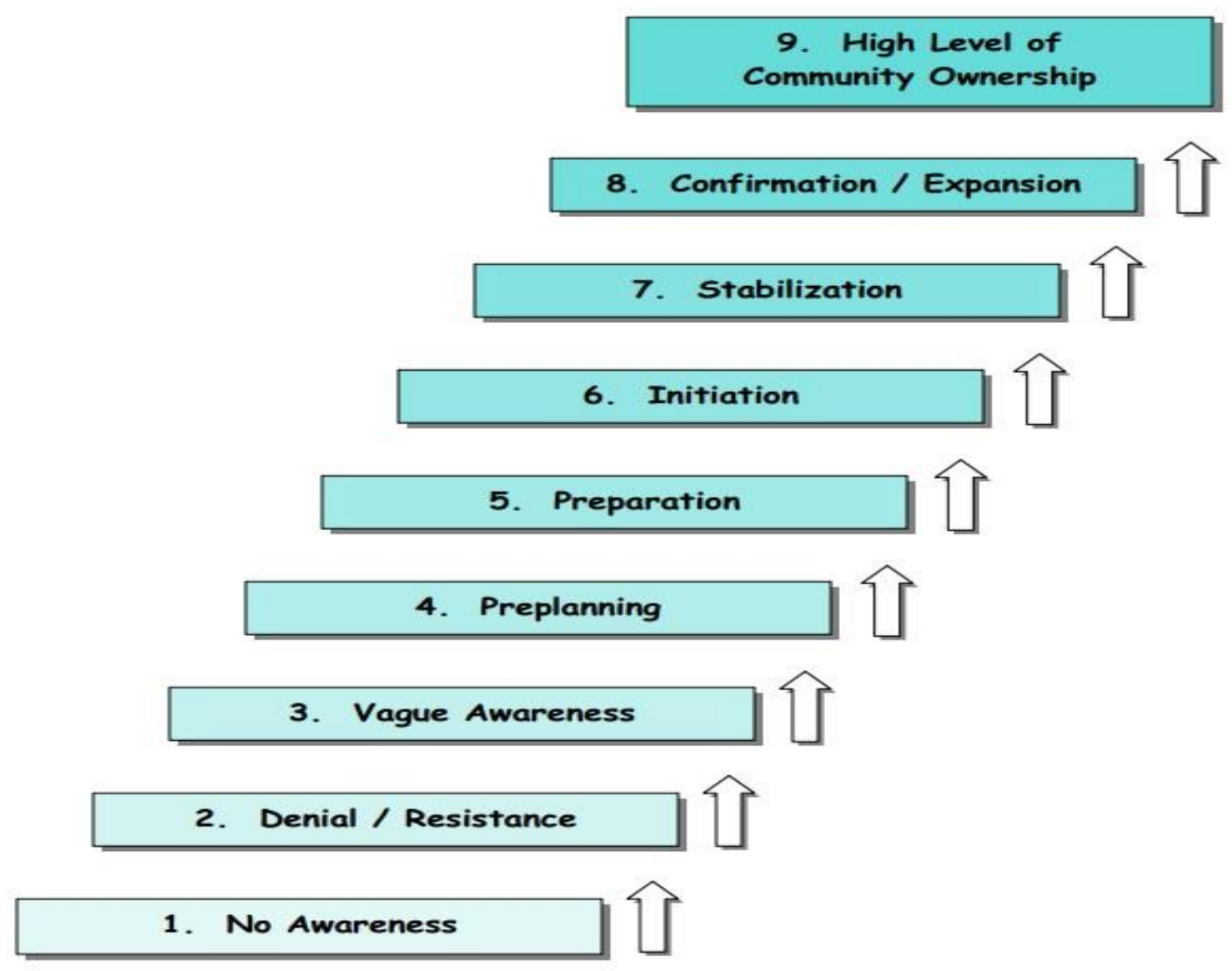

Figure 1. Level of community readiness (Plested et al., 2006)

Copyright (C 2021. Owned by Author(s), published by Society. This is an open-access article under the CC-BY-NC-SA license. 
According to Plested et al. (2006), several dimensions are used to measure community readiness, including:

1) Community efforts. It is related to the extent of community efforts to overcome certain problems.

2) Community knowledge related to efforts is the extent to which community members know the efforts made by the community to deal with problems, including whether these efforts can involve all community members.

3) Leadership. Discuss how the community chooses leaders and influential community members to solve problems.

4) Community climate. This dimension discusses the problem of how the attitude of community members in dealing with certain problems. What is this attitude taken for? Is it because of power or powerlessness?

5) Community knowledge regarding specific issues. This dimension examines the extent to which community members are aware of the problem, its consequences, and its impact on their community.

6) Resources to deal with problems. This dimension relates to the community's resources to deal with problems, such as the number of community members, time, money, and space.

\section{Research Methodology}

The method used in this research is qualitative. This method allows researchers to develop empirical field situations into interrelated patterns into a conception of the phenomenon of certain socio-cultural changes. According to Denzin \& Lincoln (2010), qualitative research focuses on the art of interpretation. Technically, researchers are required to interpret in three steps consisting of making field texts including field notes and documents; re-creating the field text in the form of an interpretation document; and producing a general text (public text) that will be present in front of the reader (Denzin \& Lincoln, 2010). The qualitative method is a method for developing the phenomenon under study, which includes a description of the actions, actors, and processes in which the action is embedded (Dey, 1993).

With qualitative methods, the research team tried to find and understand the main problems in this study, namely how the readiness of the cultural activist community and the tourism driving community for the presence of the Singhasari SEZ. Thus, the researchers obtained in-depth data to describe the condition of the community's readiness for social, cultural, and economic changes. However, it must be acknowledged that with qualitative research, the scope of the studied group (subject) becomes smaller. This is different from quantitative research, which can cover a more significant number of people being studied.

To help identify field problems, the research team managed to get into Singosari's network of cultural organizations. Since 2019, this organization has tried to oversee the development of SEZs. The goal is that SEZ Singhasari does not harm the surrounding community. In research, this network provides initial input regarding pandemic conditions and SEZ area. This network eventually became one of the research resource persons.

There are three data collection techniques carried out by researchers, such as Focus Group Discussion (FGD), interviews, and document studies. Those involved in this FGD were a research team with five members of a cultural organization in Singosari. The discussion location is outside the Singosari District area, implementing strict health protocol. The FGD event was filled with explanations of the latest Singosari conditions, the development of the SEZ project, and the general knowledge and readiness of the community. On this occasion, the research 
team also digs deeper into the readiness of this organization, both communally and individually.

The next technique used is the interview. Interviews were conducted with interviewees online using the Google Meet online communication tool. The selected resource persons for this technique are religious and cultural leaders and tourism actors who can access digital information technology facilities. Because the direct observation model by coming directly to the Singosari area is still risky, this technique is replaced by collecting secondary documents in the form of writings, pictures, or works already available. The documentation used in this research plan is regulations issued by the government, news on the implementation of the SEZ program, and pictures/photos of heritage tourism objects.

\section{Results and Discussion}

\subsection{Vague Awareness of Communities in SEZ Development}

Based on informants' searches, there has been no official socialization process that shows what and how the SEZ development will be. Information about SEZ development is spread by word of mouth, not the same language. The spread of information is not as a big tourism infrastructure project, but through different languages. Some informants called it the construction of a soccer field, a rest area, and sports facilities, and some said it was only the construction of a tourist area. One of the informants knew that there would be a big project to build a tourist spot which he often heard about from people who visited his coffee shop, and he only heard about it about a year ago. However, this informant did not know if the SEZ development would be related to cultural sites such as temples. The development of this SEZ must have been through the village's approval. Still, there has been no official socialization carried out by the village government or the organizers of the SEZ development.

The initial development process in buying land to residents in three villages has been carried out since before 2019. There is a large dry field that has been filled with soil, which is located right near the entrance of one of the villages. Many of the farmers are also in the process of selling dry land. Farmers who own land are willing to sell their fields because they are offered a higher price than the market, which causes them to start selling their land. In one village, 24 hectares of land are used to construct hotels and housing.

The three villages that are the location of this SEZ are blessed with sufficient water sources even in the dry season because the community manages a vast resource called Himpunan Penduduk Pemakai Air Minum (HIPAM). Every month the people who use water are only charged three thousand rupiahs for each cubic meter of water. According to the informant, the construction of this SEZ will disrupt their household water needs. There is also a risk of horizontal conflict among residents due to disturbances in water distribution. With reduced water catchment areas and vegetation, the temperature will be warmer, and groundwater reserves will also be depleted. The development of this physical infrastructure will certainly affect the ecological, social, and economic aspects.

The informant stated that there are two ways to disseminate information among residents. First, the sub-district head to the community conveys information regarding the SEZ development. Second, information is disseminated through rumors among citizens. However, for the first information model, it turns out that the Camat did not explain in detail the SEZ development plan. The information conveyed is only on the preparation of the hotel construction. The non-disclosure of information about SEZs transparently to the public certainly impacts the knowledge and readiness of the community. This situation places the community's 
readiness at the level of "vague awareness", which is defined as a disguised awareness (Plested et al., 2006). The boundary between the clear and the unclear becomes quite difficult to define. This means that the community of cultural activists and tourism actors know that there will be an infrastructure development plan in their area. Still, at the same time, they do not know the detailed information of the large infrastructure development project. At the same time, this is related to how community members recognize the problems that arise due to the development of tourism infrastructure (Achilich, 2015; Ayu, 2014).

The analysis of community preparedness related to SEZ is analyzed in terms of six dimensions of readiness (Plested et al., 2006). First, there are community efforts consisting of groups of cultural activists and tourism actors in dealing with the circulation of one big issue in the development plan. For cultural activists, as stated by one informant who said he had known information about SEZs since 2012, this activity was included in the formation of Meeting, Incentive, Convention, and Exhibition (MICE) tourism products. Meanwhile, tourism actors represented by informants whose livelihoods are traders and private workers feel they have to welcome the big development plan because it is related to the benefits obtained if the SEZ plan is implemented. However, they do not yet know the ecological, social, and economic impacts.

Second, the knowledge that is structured in the two communities becomes very different and, in the end, also has consequences for understanding in other communities. The knowledge of the cultural activist community was obtained from outside the development plan community. In contrast, the tourism actor community knew some from the village government and mostly from rumors circulating. So far, efforts to involve the community may be seen in cultural activists who focus on ecological issues.

Third, the leadership is still more prominent in the community of cultural activists who claim that all SEZ affairs are handled by them, including talking more about ecological issues (threats of water crisis and land sales that harm the community). Fourth, the community climate that is built tends to be a community of cultural activists because it is more about the dominance of the existence of intellectual actors. Exposure of informants said that as a community, they prefer to agree to the rules from the government.

Fifth is public knowledge. The knowledge model that is obtained incompletely and not transparently raises concerns about ecological threats such as the loss of water sources to the destruction of the heritage sites of the Singosari Kingdom. Job changes also create concern for tourism actors. Sixth, the current SEZ threatens the community early, namely the lack of clarity of information circulating in the community. Disclosure of public information is an important note to prepare the community to develop a large infrastructure.

The benchmark used in expressing the readiness of the cultural and tourism activist community is seen from the knowledge factor related to SEZ. The results of interviews that have been conducted show that these two communities know that the government has designated the Singosari District area as a Special Economic Zone. However, the source of information only came from the rumors between them. On the other hand, local governments have never transparently provided information about SEZs to the public. From this level of vague awareness, it can be seen that the readiness of the two communities is not yet clear. Community members feel that there are problems with the SEZ development process. Still, there is no motivation to do something (Plested et al., 2006), such as organizing the community to prepare for SEZ development. Thus, this study's community of cultural activists and tourism actors are categorized in a disguised readiness (vague awareness). 
As a large-scale infrastructure, information about SEZ development should be disseminated openly, so local communities know the potential or opportunities utilized and determine the potential impacts. This is because community members can recognize the problems and needs of their group (Achilich, 2015) for the changes around them. Furthermore, this community can find solutions to deal with the potential negative impacts that SEZs can later cause.

With the description of the situation above, the tourism industry promoted by SEZ Singhasari is still far from a sustainable tourism model. Sustainable tourism is generally a guarantee of increasing economic, social, ecological, and cultural welfare for the local community. Community involvement is one of the prerequisites for realizing sustainable tourism. This is because natural resources are socially constructed, and local communities are key to the conservation or destruction of natural resources utilized in such development (Richards \& Hall, 2002). The sustainable tourism model seeks to minimize negative impacts on local culture and natural resources while improving the welfare of the surrounding community. If local communities are interrelated with the tourism industry, it is possible to form sustainable tourism (Ayu, 2014).

So, involving the community of cultural activists and tourism actors in the SEZ development process in forming a sustainable tourism industry. However, this is still far from the reality when there is no disclosure of information, which causes the local community to be unprepared for a larger industrialization process.

\subsection{Community's Interpretation of SEZ Development during Pandemic}

It is undeniable that the tourism industry is the sector that has been worst hit by COVID-19. The UNWTO organization reported a decline in revenue from this sector by $22 \%$ in the first four months of 2020. Meanwhile, in March 2020, there was a decline in revenue of around USD 80 billion (United Nations World Tourism Organization, 2020). There are around 50 million jobs in the global tourism sector with the potential to be lost (Faus, 2020). The International Labour Organization (ILO) also calculates that in 14 Asia Pacific countries, there are 15.3 million tourism sector workers, with a composition of 6.4 million women and 8.9 million men, at risk of the COVID-19 pandemic. Not to mention that informal workers in the tourism sector are also affected (International Labour Organization, 2020).

Apart from impacting tourism sector workers, COVID-19 has also changed the behavior of world tourists. Uğur \& Akbiyık (2020) conducted research by searching in the comments section of the TripAdvisor app. They found that travel delays or cancellations were common during the study due to the increasing outbreak of COVID-19 and the spread of information around the world regarding this pandemic. The demand for travel insurance is also an important finding of this study (Uğur \& Akbiyık, 2020).

In addition to the economic and behavioral impacts above, what deserves attention is ensuring the safety of tourism actors. So, safety is important for humans during uncertainty and the emergence of risks due to the pandemic (Federici, 2020). Uncertainty arises from the contradictions created by the pandemic. For example, the social distancing policy in human activities to reduce the risk of transmission is a form of contradiction of human social nature, which always needs to interact directly (Federici, 2020). Using Federici's perspective, the construction of the Singhasari SEZ during this pandemic also shows the contradictions of the situation.

One of the interviews with cultural activists through Google Meet stated that regional development based on physical infrastructure is no longer needed. This is because regions,

Copyright (C 2021. Owned by Author(s), published by Society. This is an open-access article under the CC-BY-NC-SA license. https://doi.org/10.33019/society.v9i2.298

498 
centers, or areas need to be re-understood to become no longer physical but digital spaces. This is in line with the emergence of the COVID-19 pandemic, which forces humans to keep their distance and reduce direct interaction. In addition, the development of digital technology also affects how the interaction between humans changes. The development of physical infrastructure in the SEZ is no longer needed because it has been replaced by digital technology and triggered by pandemic conditions. The development of the SEZ in the heritage tourism sector is in contrast to the innovations made by the tourism industry during the pandemic (Gunagama et al., 2020).

Thus, the emergence of risk and uncertainty due to the pandemic creates the need for guarantees for human safety. Human safety is not only related to tourists, but local communities must also be guaranteed their safety. Then, has the guarantee of human safety been obtained by the community of cultural activists and tourism actors in this research? COVID-19 pandemic did not change the plan for the development of the Singhasari SEZ in the three villages. Because it has been ratified through Government Regulation of the Republic of Indonesia Number 68 of 2019, this national project covering an area of 120.3 hectares will continue as a center for developing the tourism industry and a digital technology development zone. The COVID-19 pandemic will not stop the development process but will only slow it down. But unfortunately, during the research process, there was no discourse on guaranteeing safety for the cultural and tourism activist community, both in terms of health, livelihoods, and access to natural resources.

On the other hand, the FGD process with members of cultural activist organizations found another perspective. Members of this organization stated that COVID-19 was "God's punishment" both for SEZ developers, the government, and the private sector. The punishment is in the form of not immediately completing the SEZ Singhasari. With the outbreak with a social restriction mitigation model, the development process is not as smooth as before the pandemic. For example, the existence of Large-Scale Social Restrictions (LSSR) throughout May 2020, due to the high spike in positive cases in Singosari District, made the development process run slowly. For example, the process of buying and selling land between land-owning farmers and SEZ developers is not as fast as before the pandemic.

It will be interesting to see how this interpretation of "God's punishment" develops among the discussion participants. This interpretation arises when information on SEZ development is not openly conveyed to the public. Likewise, the local government has never officially discussed and socialized the impact assessment if the SEZ is built. Many questions were raised in this discussion, such as how the distribution of water that the community should easily own diverted for SEZ development? How many hectares of land will be converted into tourist sites? Is there a location for a cultural heritage site from the Singosari Kingdom that will bear the risk of damage if the construction process is carried out? What about economic inequality when the SEZ has been built? Will this project bring economic and ecological prosperity to local communities in a sustainable manner?

The interpretation above is not born out of anywhere. The closure of public information and SEZs development eventually gave vague awareness. From this vague awareness model, it is finally correlated with giving an interpretation of the pandemic disaster. The embedding of the term "punishment from God" is addressed to the local government and private parties who are the initiators and developers of the Singhasari SEZ. The pandemic is a punishment from God for those who do not provide sufficient information for the people affected by the SEZ development. 
How a pandemic event is considered a catastrophic event can be seen through Huet's work. Through the book "The Culture of Disaster", Huet (2012) explained that the cholera epidemic that hit Europe in 1831 was more than a mere public health problem. More than that, Huet pointed out that the cholera epidemic was a matter of political and social control. From there, he stated that the outbreak of the event opened the veil of the local community's character and tested the patterns of government policies.

So, when there is an SEZ development policy, and the public only knows the information through rumors, it shows how the government treats its citizens in terms of public information. Even so, with the description of how the government and private SEZ developers when a pandemic emerged, there was no single model of assistance to the community in and around the construction site, showing how residents were treated. The people of the three villages are not the subject of the development of the tourism industry. They are just spectators and land sellers.

\section{Conclusion}

The research that we have done shows that the community's readiness for cultural activists and tourism movers is at the level of vague awareness. Until more than one year in the development process, namely mid-2020, informants only knew that information on SEZ development came from rumors among themselves. The information from local officials was never obtained in detail. This is allegedly related to the closed public information related to the SEZ development process.

On the other hand, the COVID-19 pandemic has hampered the development of SEZ, which was interpreted by informants as a form of punishment from God to the organizers and developers of SEZ due to the lack of information submitted to the public. The absence of safety and health guarantees for residents during a pandemic is also an important finding in this research. If this condition continues, the local community may be treated not as an active subject of development but only as a passive development object. This situation can potentially affect the participatory and sustainable tourism industry development model.

\section{Acknowledgment}

The authors are grateful to express gratitude to those who have had the pleasure to cooperate during this research.

\section{Declaration of Conflicting Interests}

The authors have declared no potential conflicts of interest concerning the study, authorship, and/or publication of this article.

\section{References}

Achilich, K. D. (2015). Using The Community Readiness Model as a Framework to Understand a Community's Preparedness to Increase Food Access (Master's dissertation). University of Vermont. Retrieved from https:/ / scholarworks.uvm.edu/graddis/504/

Ayu, R. (2014). Sustainable Tourism on Semau Island: Ready or not? Journal of Tourism $\mathcal{E}$ Hospitality, 03(03). https:/ / doi.org/10.4172/2167-0269.1000133 
The Vague Awareness of Communities in the Singhasari Special Economic Zone Development during the COVID-19 Pandemic

Candra, L. F. K., \& Rekha, A. (2020). The Effects of Pandemic Era to Tourism Industry in Tangerang. Journal of Indonesian Tourism, Hospitality and Recreation, 3(2), 169-175. https:/ / doi.org/10.17509/jithor.v3i2.25664

Denzin, N. K., \& Lincoln, Y. S. (2010). Handbook of Qualitative Research. Yogyakarta, Indonesia: Pustaka Pelajar.

Dewan Nasional Kawasan Ekonomi Khusus Republik Indonesia. (2019). KEK Singhasari. Retrieved from https://kek.go.id/kawasan/KEK-Singhasari

Dey, I. (1993). Qualitative Data Analysis: A User Friendly Guide for Social Scientists (1st ed.). London, United Kingdom: Routledge.

Dinas Kebudayaan dan Pariwisata Kabupaten Malang. (2015). Rencana Strategis Dinas Kebudayaan dan Pariwisata Kabupaten Malang 2011-2015. Malang, Indonesia: Author.

Edwards, R. W., Jumper-Thurman, P., Plested, B. A., Oetting, E. R., \& Swanson, L. (2000). The Community Readiness Model: Research to Practice. Journal of Community Psychology, 28(3), 291-307.

Fathurrahim, F. (2020). Pariwisata NTB dalam Lingkaran COVID-19. Media Bina Ilmiah, 15(2), 4057-4062. https:/ / ejurnal.binawakya.or.id/index.php/MBI/article/view/703

Faus, J. (2020, March 17). This is how coronavirus could affect the travel and tourism industry. Retrieved from https://www.weforum.org/agenda/2020/03/world-travel-coronaviruscovid19-jobs-pandemic-tourism-aviation/

Federici, R. (2020). An Uncertain Global Environment. Social Extremity, and Sociology of COVID-19. Biomedical Journal of Scientific $\mathcal{E}$ Technical Research, 26(4). https:/ / doi.org/10.26717/bjstr.2020.26.004388

Gunagama, M. G., Naurah, Y. R., \& Prabono, A. E. P. (2020). Pariwisata Pascapandemi: Pelajaran Penting dan Prospek Pengembangan. LOSARI : Jurnal Arsitektur Kota Dan Pemukiman, 56-68. https:/ / doi.org/10.33096/losari.v5i2.76

Huet, M.-H. (2012). The Culture of Disaster. Chicago, Illinois: The University of Chicago Press.

International Labour Organization. (2020, April 24). COVID-19 and employment in the tourism sector: Impact and response in Asia and the Pacific. Retrieved from https://www.ilo.org/asia/publications/issue-briefs/WCMS_742664/lang-en/index.htm

Kaushal, V., \& Srivastava, S. (2021). Hospitality and tourism industry amid COVID-19 pandemic: Perspectives on challenges and learnings from India. International Journal of Hospitality Management, 92, 102707. https:/ / doi.org/10.1016/j.ijhm.2020.102707

Krisnawati, L., \& Suprihardjo, R. D. (2014). Arahan Pengembangan Kawasan Cagar Budaya Singosari Malang sebagai Heritage Tourism. Jurnal Teknik Pomits, 3(2), 154-159. Retrieved from https:/ / ejurnal.its.ac.id/index.php/teknik/article/view/7249

Lintjewas, A. R., Franklin, P., \& Rate, J. V. (2015). Studi Kesiapan Masyarakat terhadap Rencana Pengembangan Kawasan Ekonomi Khusus di Kota Bitung. Spasial : Perencanaan Wilayah Dan Kota, 2(1), 48-54. Retrieved from https:/ / ejournal.unsrat.ac.id/index.php/spasial/article/view/8300

Nian, S., Zhang, J., Zhang, H., Zhang, J., Li, D., Wu, K., . . Yang, L. (2019). Two Sides of a Coin: A Crisis Response Perspective on Tourist Community Participation in a Post-Disaster Environment. International Journal of Environmental Research and Public Health, 16(12), 2073. https:/ / doi.org/10.3390/ijerph16122073

Nunkoo, R., \& Ramkissoon, H. (2011). Developing a community support model for tourism. Annals of Tourism Research, 38(3), 964-988. https:/ / doi.org/10.1016/j.annals.2011.01.017

Copyright (C 2021. Owned by Author(s), published by Society. This is an open-access article under the CC-BY-NC-SA license. https://doi.org/10.33019/society.v9i2.298

501 
The Vague Awareness of Communities in the Singhasari Special Economic Zone Development during the COVID-19 Pandemic

Plested, B. Edwards, R. W., \& Jumper-Thurman, P. (2006). Community Readiness: A handbook for successful change. Sage Hall, Colorado State University: Tri-Ethnic Center for Prevention Research,. Retrieved from https://tec.colostate.edu/wpcontent/uploads/2018/04/CR_Handbook_8-3-15.pdf

Rachman, N. A., \& Syamsudin, S. (2019). Analisis Persepsi dan Kesiapan Masyarakat Pandeglang dalam Menghadapi Pelaksanaan Kawasan Ekonomi Khusus (KEK) Zona Pariwisata Tanjung Lesung. Sains Manajemen, 4(2), 107-124. https:/ / doi.org/10.30656/sm.v4i2.843

Republik Indonesia. (2019). Peraturan Pemerintah Republik Indonesia Nomor 68 Tahun 2019 Tentang Kawasan Ekonomi Khusus Singhasari. Lembaran Negara Republik Indonesia Tahun $2019 \quad$ Nomor $176 . \quad$ Retrieved from https:/ / peraturan.go.id/common/ dokumen/ln/2019/pp68-2019bt.pdf

Riadil, I. G. (2020). Tourism Industry Crisis and its Impacts: Investigating the Indonesian Tourism Employees Perspectives' in the Pandemic of COVID-19. Jurnal Kepariwisataan: Destinasi, Hospitalitas Dan Perjalanan, 4(2), 98-108. https:/ / doi.org/10.34013/jk.v4i2.54

Richards, G., \& Hall, D. (2002). The community: a sustainable concept in tourism development? In G. Richards \& D. Hall (Eds.), Tourism and Sustainable Community Development (2nd ed., pp. 1-13). London, United Kingdom: Routledge.

Rosyadi, S. (2021). Government Capacity in Recovering Tourism Sector in the Pandemic Period: Comparison between Indonesia and Thailand. Insignia Journal of International Relations, Edisi Khusus "Navigating Global Society in the Disruptive Era", 48-56. Retrieved from http://jos.unsoed.ac.id/index.php/insignia/article/view/3827

Uğur, N. G., \& Akbiyık, A. (2020). Impacts of COVID-19 on global tourism industry: A crossregional comparison. Tourism Management Perspectives, 36, 100744. https:// doi.org/10.1016/j.tmp.2020.100744

United Nations World Tourism Organization. (2020). Impact assessment of the COVID-19 outbreak on international tourism | UNWTO. Retrieved from https:/ / www.unwto.org/impact-assessment-of-the-COVID-19-outbreak-oninternational-tourism

\section{About the Authors}

1. Lutfi Amiruddin obtained his Master's degree from Universitas Gadjah Mada, Indonesia, in 2012. The author is an Assistant Professor at the Department of Sociology, Faculty of Social and Political Sciences, Universitas Brawijaya, Indonesia. His research interests are disaster study and tourism study.

E-Mail: amiruddin.lutfi@ub.ac.id

2. Genta Mahardhika Rozalinna obtained her Master's degree from Universitas Gadjah Mada, Indonesia, in 2014. The author is an Assistant Professor at the Department of Sociology, Faculty of Social and Political Sciences, Universitas Brawijaya, Indonesia. Her interests are studying women in ecology and the sociology of corruption.

E-Mail: gmrozalinna@ub.ac.id 
The Vague Awareness of Communities in the Singhasari Special Economic Zone Development during the COVID-19 Pandemic

3. Primadiana Yunita obtained her Master's degree from Universitas Gadjah Mada, Indonesia, in 2015. The author is an Assistant Professor at the Department of International Relations, Faculty of Social and Political Sciences, Universitas Brawijaya, Indonesia. E-Mail: primadiana@ub.ac.id 